\title{
Host immune responses to nematodes: benefit or cost? Implications for future development of sustainable methods of control
}

\author{
Andrew R. Sykes ${ }^{1}$ \\ ${ }^{1}$ Department of Agricultural Sciences, Faculty of Agriculture and Life Sciences, PO Box 84, Lincoln University, Lincoln, New Zealand.
}

\begin{abstract}
The nutritional and production costs associated with the development of a competent immune response against nematode parasites is described, based on data from sheep. Anorexia and changes in metabolism are considered to be driven by the host immune response itself and the question is raised about the wisdom of seeking to strengthen immune responses by genetic selection. Several phases of the immune response are identified with different implications for loss of productivity and opportunity for moderation of immune responses and production losses by nutrition. Many animals are able to manage nematode infections with little loss of productivity. In an era when attempts are being made to reduce anthelmintic use and create refugia to reduce the rate of development of drench resistance, treatments based on individual animal performance relative to production targets set by assessment of the prevailing nutritional environment will become more common. These developments, have already occurred in relation to the haematophagic nematodes, for example the "Famacha" technique. Computer-aided weighing and drafting has potential for use with the less pathogenic nematodes prevalent in temperate regions though we need to know more about the pathophysiology and nutritional costs of infections with Nematodirus spp.
\end{abstract}

Key Words: host immuno-pathology, nematodes, targeted specific treatments (TST)

\section{Resposta imune a nematódeos: vantagem ou custo? Implicações para o desenvolvimento futuro de métodos sustentáveis de controle}

RESUMO - Os custos nutricionais e de produção associados ao desenvolvimento de uma resposta imune competente contra parasitas nematódeos estão descritos nesta revisão, com base em dados com ovinos. Anorexia e mudanças no metabolismo são consideradas o resultado da própria resposta imune do hospedeiro, e a questão é levantada quando se busca o fortalecimento da resposta imune pela seleção genética. Várias fases da resposta imune são identificadas com diferentes implicações, pela perda de produtividade e oportunidade para moderação da resposta imune e pela perda da produção pela nutrição. Muitos animais são capazes de lidar com as infecções por nematódeos com pouca perda de produtividade. Numa era em que se se visa à redução do uso de anti-helmínticos e a alternativas para redução da taxa de desenvolvimento de resistência, tratamentos com base no desempenho individual do animal relacionado à produção e que sinalizam pela avaliação do ambiente nutricional serão mais comuns. Esses progressos já ocorrem com nematódeos hematófagos, por exemplo, a técnica de "Famacha". Pesagem e projetos auxiliados por computador têm o potencial de uso em nematóteos menos patogênicos prevalentes em regiões temperadas, apesar de ser necessário melhor conhecimento sobre fisiopatologia e custos nutricionais de infecções com Nematodirus spp.

Palavras-chave: alvos com tratamento específico, imunopatologia do hospedeiro, nematóides

\section{Introduction}

The widespread evidence for developing drug resistance in nematode populations during the last two decades is shifting the emphasis in livestock production systems from anthelmintic regimes which maximise livestock production to regimes which optimise livestock production while slowing or preventing the development of anthelmintic resistance. A major objective of the change has been to reduce selection pressure on the nematodes by maintaining significant populations outside the animal 'in refugia'
(Jackson et al., 2009). The implications of this are an expectation of a greater continuous nematode larvae intake and, as a consequence, reduced productivity.

A second line of attack has been the introduction of genetic selection programmes for animals, particularly sheep, with greater resistance to nematodes. The mass screening techniques necessary to deal with large populations have meant that nematode eggs in faeces (FEC) have been adopted as a simple indirect measure of host immune responses. Evidence suggests that enhanced ability to control FEC may be associated with reduced animal performance. 
Two issues have therefore assumed major importance in research. How important is a strong immune response and are FEC an appropriate tool for decision making on when to use anthelmintics?

\section{The immune response}

The immune response evolves from a non-specific 'innate' to a more specific adaptive or acquired immune response. The former is generally considered to be more costly, nutritionally, than the adaptive response. Penetration of the gastrointestinal tissues of the host activates macrophages and other cells with receptors for cell surface molecules on the nematode which induces a general inflammatory response. Antigen specific responses stimulate recruitment, direction to site and activation of leucocytes, particularly eosinophils, by a combination of mucosally produced antibodies, such as IgA and signalling of pro-inflammatory cytokines (ILI, IL6 and TNF- $\alpha$ ). A secondary feature is the production of acutephase proteins in liver and intestinal tissue which are considered to be host tissue protective.

Adaptive immunity evolves through the antigenspecific programming of lymphocytes and leucocytes such as eosinophils and stimulation of the latter to degranulate and release highly toxic proteins, oxidising agents and neurotoxins in proximity to the nematodes in tissue. A different sub-set of cytokines (including IL5, IL4, IL10 and IL13 - Th2 cytokines) are considered to be involved and may also drive the recruitment of mucosal mast cells (MMC) and their regulating antibody (IgE). It is the ultimate establishment of MMC and their regulatory armature which appears to provide the effector mechanism for the memory-based mature 'acquired' or adaptive immune response.

The resources deployed are a trade-off between the cost of diverting host defence mechanisms towards an active immune response and the risk of excessive immune system activity leading to self-inflicted immunopathology (Graham et al., 2005). These trade-offs have short and long term genetic components - individual host genotypedriven life history traits, such as growth and reproduction, and longer term population survival genetic components.

The escalating costs of mounting a more effective immune response to eliminate the last members of a parasite population under partial control by the host immune response were identified by Behnke et al. (1992) as the reasons for the failure of vertebrate hosts to have evolved sterilizing immunity against most gastrointestinal nematodes. The costs and trade-offs in sheep populations were described by Greer (2008) and Colditz (2008) summarised 6 avenues through which this immune cascade would provide a resource (nutritional) cost to the host:

1. increased metabolic activity during activation of immune system cells; recruitment of millions of leucocytes occurs and their activation can increase oxygen consumption, glucose and glutamine utilization 2 to 3 fold (Colditz, 2008).

2. reduced nutrient availability due to anorexia and sickness behaviour;

Anorexia is a common feature of infection with most nematodes and the precise physiological reason is not known. More recent studies, in which appetite depression in naïve lambs infected with either abomasal or intestinal nematodes, was abolished by immuno-suppressed with corticosteroids (Greer et al., 2005, 2008a) has suggested that immune system signalling closely associated with the generation of IgA antibody could be responsible. The anorexia seems to be associated with the acquisition of immunity, since older animals with established immunity do not show anorexia during larval challenge or change in feed intake when immune suppressed (Greer et al., 2005).

3. altered priorities for nutrient utilization during immune activation that reduce the capacity of many nonimmune tissues to utilise nutrients; the general trend is for increased protein catabolic activity in skeletal muscle and increased anabolic activity in the liver and the alimentary tract (Yu et al., 2000). The mechanism is not well understood though resistance to the anabolic effect of insulin, growth hormone and IGF-1 reduces nutrient utilization in peripheral tissues. These changes in settings, probably under cytokine stimulation, are consistent with the need for the acute phase protein response in the liver and GIT and the fact that muscle tissue is a prime source of glutamine, an important nutrient for leucocytes of the immune system (Lobley et al., 2001).

4. change in size and rate of turnover of cell and protein pools of the immune system; the immune response involves rapid multiplication of subsets of $\mathrm{T}$ lymphocytes which have not been quantified other than in 1 above;

5. damage to host tissue caused by inappropriate or excessive activity of the immune system (immunopathology) and cost of repair;

Infections during which immune responsiveness has been suppressed using the glucocorticoid methyl prednisolone acetate (Nagasinha, 2000; Greer et al., 2005, 2008a) have shown that populations of nematodes much larger than those associated with severe production loss or even clinical disease (Sykes \& Coop, 1976) can be maintained during primary infection without loss of performance. These 
studies indicate that much of the pathology of infection is self- (ie host) inflicted.

Immunosuppression did not prevent the typical increase in leakage of plasma proteins into the gastrointestinal tract (Vaughan et al., 2006). Moreoever, both the extent of depression of appetite and the nutritional costs associated with immuno-pathology were increased with low protein intake (Greer et al., 2008b). These findings raise the question "what is the 'appropriate' immune response and are genetic selection programmes for stronger immune responses appropriate, particularly if these have adverse effects on appetite and nutrient utilisation?” The answer may well vary with the nutritional environment in which the animal is expected to perform.

6. consequential 'long term' genetic cost from change in capacity of offspring to express production and life history traits following selective breeding or natural selection for disease resistance.

On the evidence that immune responses have costs associated with delivery it is relevant to ask how the evolutionary process has dealt with this. This was addressed in reviews by Coldtz (2008) and Greer (2008). Perhaps unsurprisingly there is evidence for unfavourable genetic correlations between FEC and liveweight and fleece weight. Breeding lines selected for increased fleece weight, lamb growth rate or productivity indices had higher FEC (Howse et al., 1992; Morris et al., 1996; Eady et al., 1998) and the latter authors estimated that genetic selection for productivity would lead to a $1 \%$ per annum increase in FEC. Conversely flocks selected for low FEC have shown negative effects on lamb weight gain and wool production (Morris et al., 2000, 2005), though there are findings to the contrary (Bishop \& Stear,1999). Resistance to nematode parasites is a highly polymorphic trait and the precise immune responses invoked and their pathophysiological consequences could vary between populations and, as shown above, as a consequence of the particular nutritional and challenge environment. Suffice to say that in management of flocks and future breeding programmes care will be needed to understand the particular dynamic partitioning of nutritional resources between the immune system and production traits, and that this may vary between genotypes, and within genotypes during an individual's lifetime and as a consequence of its current nutritional environment.

\section{The immune response and productivity}

In a recent review Sykes (2008) argued that four phases can be identified in the immune response of the sheep host. The first, hypo-responsive phase, appears to occur between birth and 2-3 months of age. The reasons for this are unclear; it may simply indicate an immaturity of the immune cell system (Watson et al., 1994; Kambara et al., 1996) or programmed prioritization of nutrients towards tissue growth and away from the immune system in rapidly growing lambs (Coop \& Kyriazakis, 1999). McClure \& Emery (2007) observed that the ability of weaned Merino wether lambs to limit FEC and worm burdens under secondary challenge was directly related to bodyweight during primary challenge, with bodyweight in excess of $23 \mathrm{~kg}$ being critical for good vaccinating response suggesting hyporesponsiveness at immature bodyweights .

If immune responses are a major cause of pathology and anorexia of infection it may well be that, despite significant FEC effects of infection on productivity could be small during this phase. In of the few studies of this phase Iposu et al. (2008) were unable to measure effects of infection with T. circumcincta larvae in either suckled or early weaned weaned lambs between 6-12 weeks of age, even though the latter had much poorer protein supply. Productivity was simply determined by nutrient (milk) supply. This raises the question as to the value of anthelmintic treatment during this phase for production benefit.

The ability to exclude nematodes from tissues is acquired during the second phase and, in 3-4 month, old, previously naïve $30 \mathrm{~kg}$ lambs this occurs after about 8 weeks of infection (Symons et al., 1981; Sykes \& Coop, 1976; Kimambo et al., 1988) and, as indicated earlier may be dependent on body maturity (McLure \& Emery, 2007).

It is during this period of acquisition of immunity that animal productivity is most severely affected. Earlier ideas that productivity was reduced by nutrient sequestering by the nematode population,or reduced ability to digest and absorb nutrients is being replaced by the notion that the host immune response per se is responsible. Depression of feed intake, of up to $50 \%$ can occur even in subclinical infections (Coop \& Sykes 2002), and net energy (NE) deposited relative to metabolisable (ME) intake can be reduced from typical values of $20 \%$ to less than $15 \%$. It is the damaging effects for productivity of this 'acquisition'phase of the immune response against which most anthelmintic regimes are directed and have major benefit. There is good evidence that the duration of this phase, and therefore the consequences for productivity can be shortened by increased nutrient supply, particularly protein (see reviews by van Houtert \& Sykes, 1996; Coop \& Sykes, 2002) and there is direct evidence for effect of enhanced amino acid supply on the rate of development and activity of gastrointestinal mucosal mast cells involved in the mature immune response (Coop et al., 1995). 
The third phase is when the host is able to limit the ability of larvae to penetrate tissues and establish. The production costs of this "mature" immunity, though not negligible, are much smaller. Eighteen-month-old sheep with established immunity and exposed to similar rates of infection to younger naïve lambs entering the acquisition phase suffered only 5 and $10 \%$ reductions in intake and NE:ME ratio, respectively, compared to $20-50$ and $20-30 \%$ reductions, respectively in the lambs (Greer et al., 2005). In a breeding flock annual bodyweight disadvantages of $3-5 \mathrm{~kg}$ and a reduction of $8 \%$ in number of foetuses/100 ewes have recently been attributed to nematode larval intake in mature sheep given continuous anthelmintic treatment by slow release anthelmintic capsules (West et al., 2009).

The fourth "mature-interrupted" phase typically occurs around parturition and is described by a peri-parturient relaxation of immunity (PPRI) seen in a rise in FEC. The precise cause is unknown, but increased competition for nutrients between the developing foetus or lactation with the immune system have been postulated (Coop \& Kyriazakis, 1999). Recovery of immunity generally occurs within 6 weeks of parturition (O'Sullivan \& Donald, 1970; McAnulty et al., 2001), but PPRI and recovery are associated with anorexia, exaggerated peri-parturient weight loss and earlier decline from peak milk production (Leyva et al., 1982; Zaralis et al., 2009). As with the acquisition phase nutrient supply is important in determining the extent and duration of the PPRI. Positive effects of regimes which enhance ewe body condition at parturition (Kahn et al., 2003) dietary protein supply (Donaldson et al., 2001; Houdijk et al., 2003) or of body protein reserves at parturition (Houdijk et al., 2001) have been most effective. It is now clear that the immune system is more sensitive (i.e. is allocated a lower priority) to protein supply than milk production (Houdijk et al., 2003, 2009) and that the protein requirement for maintenance of immunity around parturition is at least $30 \%$ higher than conventional estimates of protein requirement of lactating ewes (Donaldson et al., 2001; Houdijk et al., 2003, 2009).

\section{Resistance or resilience- which option is best?}

The finding that host immune responses may be the cause of pathology and production loss, and the findings that the consequences that these can be moderated by nutrition is leading to a re-appraisal of our approach to control measures and to greater focus on the periods when immune responses may be limiting production. It is also questioning the wisdom of selecting animals capable of maintaining low FEC. Are we, as a consequence, selecting animals with strong immune responses, whose demands lead to compromised productivity? It is raising again the issue of what we mean by the much used terms "resistance" and 'resilience' to infection. Ideally, in a production sense we seek animals with resilience to infection. But we are now beginning to ask whether this is best achieved through increasing resistance (greater ability to limit worm burden, now with implied costs of the strong immune response) or selecting animals that commit less to the immune response and are therefore more resilient because appetite is maintained and immunopathology is constrained. This really begins to describe the ideal nematode-host relationship as "commensal" in which there is minimal cost to both partners. We are beginning to wonder, especially with temperate nematodes such as $T$. circumcincta and $T$. colubriformis whether there are individuals in flocks which can manage a more commensal relationship because of lesser commitment of immune resources and whether this will depend on the nutritional environment they encounter. Le Jambre (2005) has argued the possibility of a closer commensal relationship with these nematodes due to co-evolution in central Asia and the greater pathogenicity of Haemaonchus and Oesophagostomum spp. due to their evolution in African ruminants such as antelope and more recent association with sheep as they moved to Africa. Recent work is suggesting that there are substantial numbers of sheep in flocks which manage a more commensal relationship with nematodes than their contemporaries.

\section{Implications for flock and herd management}

Until now anthelmintic treatment to prevent clinical and sub-clinical disease has been based on mass medication since there have been poor tools, including FEC, to detect only those animals in need of treatment. This approach has had the benefit of limiting continuing larval contamination of pasture but the desireability of this is now being questioned with the desire to create refugia. The development of computerisation of weighing and drafting of animals is shifting thinking towards the development of targeted specific treatments (TST) in which individual animals are treated on the basis of productivity rather than FEC or an epidemiological strategy (Greer et al., 2009; Kenyon et al., 2009). This approach is predicted on an accurate assessment of the quality and availability of pasture and consequent growth rate target for the group of animals. These studies, in which only those animals which did not achieve greater than $66 \%$ of the targeted growth performance were treated with anthelmintic, showed no reduction in flock mean growth rate compared to animals given traditional mass routine monthly preventative treatments, even though the number of drench treatments/lamb was reduced by more 
than 50\%. This approach will in the longer term, facilitate the selection of "resilient" animals which perform in the face of larval challenge. Whether they do so because they can manage the nematode population with less immunopathology and anorexia is yet to be determined, as will be the consequences of any build up in magnitude of larval challenge. They have already demonstrated potential in slowing the build up of drug resistance in the nematode.

It should be said that these findings and approaches have been based on work with the nematodes of major economic importance in temperate regions and whose relationship with the host tends towards the commensal. With nematodes with a more exploitative and demanding relationship with the host, such as the haemotophagic nematode $H$. contortus, the situation may be very different. It is difficult to foresee a commensal relationship with this nematode and a strong and rapid immune response, though at significant cost to the host, may be a more successful one in the longer term. Consistent with this hypothesis, sheep with resistance to this nematode, for example the Red Masai, have notoriously poor productivity. Moreover, it is perhaps no coincidence that comparable studies to those with $T$. circumcincta and colubriformis have not shown production advantages from immune suppression in studies with H. contortus (Morley, 2006). However, the TST approach outlined above of treating with anthelmintic on the basis of host impairment rather than FEC has already been established for some time in the FAMACHA technique (van Wyk \& Bath, 2002), treatment being based on the degree of anaemia observed on clinical observation and comparison with objective score against standardised eye charts, and proven to be quantitative and effective.

There is concern about whether TST approaches will work with Nematodirus spp. This nematode's ability to survive for long periods outside the host and very rapid development when climatic conditions are suitable (Pomroy, 1997) may mean that the host could be overwhelmed before detection in depression of performance. It is the nematode to which most rapid development of immunity is considered to occur (Dineen \& Wagland, 1982). Developing larval stages penetrate the sub-mucosal tissues of the host (Balic et al., 2000)) probably to a greater degree than is the case with most economically important nematodes. If the extent of damage caused in this niche is particularly debilitating the evolutionary trade-off may have been a particularly strong immune response even at the risk of incurring damaging immunopathology. There is surprisingly no data on the nutritional pathology of Nematodirus spp. such as is available for infections with
T.circumcincta or T. colubriformis/vitrinus, but sudden unexpected deaths of animals with evidence of strong intestinal inflammatory reactions suggest that the nutritional and metabolic costs of host immune responses need to be quantified. There is strong advocacy from 'Wormwise' a National Technical Advisory Committee on Parasite Control in New Zealand to obtain this information for the planning and development of TST strategies.

\section{Conclusions}

Pathology and loss of productivity in nematode infections is the result of host immune responses during the phase of acquisition of immunity. In the future whole flock or herd anthelmintic treatment approaches will be replaced by treatments specifically targeted only to those individuals whose performance is compromised by the evolving immune response. They will be based on the failure to meet performance targets calculated from available feed supplies rather than faecal egg count.

\section{References}

BALIC, A.; BOWLES, V.M.; MEUSEN, E.N.T. The immunobiology of gastrointestinal nematode infections in ruminants. Advances in Parasitology, v.45, p.182-241, 2000.

BEHNKE, J.M.; BARNARD, C.J.; WAKELIN, D. Understanding chronic nematode infections: evolutionary considerations, current hypotheses and the way forward. International Journal for Parasitology, v.22, p.861-907, 1992.

BISHOP, S.C.; STEAR, M.J. Genetic and epidemiological relationships between productivity and disease resistance: gastrointestinal parasite infection in growing lambs. Animal Science, v.69, p.515-524, 1999.

COLDITZ, I.G. Six costs of immunity to gastrointestinal nematode infections. Parasite Immunology, v.30, p.63-70, 2008.

COOP, R.L.; HUNTLEY, J.F.; SMITH, W.D. Effect of dietary protein supplementation on the development of immunity to Ostertagia circumcincta in growing lambs. Research in Veterinary Science, v.59, p.24-29, 1995.

COOP, R.L.; KYRIAZAKIS, I. Nutrition-parasite interaction. Veterinary Parasitology, v.84, o.187-204, 1999.

COOP, R.L.; SYKES, A.R. Interactions between gastrointestinal parasites and nutrition. In: FREER, M.; DOVE, H. (Eds.) Sheep nutrition. Wallingford: CABI International, 2002.

DINEEN, J.K.; WAGLAND, B.M. Immunoregulation of parasites in natural host-parasite systems - with special reference to the gastrointestinal nematodes of sheep. In: SYMONS, L.E.A; DONALD, A.D; DINEEN, J.K. (Eds.) Biology and control of endoparasites. Sydney: Academic Press, 1982. p.297-329.

DONALDSON, J.; van HOUTERT, M.F.J.; SYKES, A.R. The effect of dietary fish-meal supplementation on parasite burdens of peri-parturient sheep. Animal Science, v.72, p.149-158, 2001.

EADY, S.J.; WOOLASTON, R.R.; LEWER, R.P. et al. Resistance to nematode parasites in Merino sheep: correlation with production traits. Australian Journal of Agricultural Research, v.49, p.1201-1211, 1998.

R. Bras. Zootec., v.39, p.376-382, 2010 (supl. especial) 
GRAHAM, A.L.; ALLEN, J.E.; REID, A.F. Evolutionary causes and consequences of immunopathology. American Review of Ecology and Evolutionary Systems, v.36, p.373-379, 2005.

GREER, A.W.; KENYON, F.; BARTLEY, D.J. et al. Development and field evaluation of a decision support model for anthelmintic treatments as part of a targeted selective treatment (TST) regime in lambs. Veterinary Parasitology, v.164, p.12-20, 2009.

GREER, A.W. Trade-offs and benefits: implications of promoting a strong immunity to gastro-intestinal parasites in sheep. Parasite Immunology, v.30, p.123-132, 2008.

GREER, A.W.; STANKIEWICZ, M.; JAY, N.P. et al. The effect of concurrent corticosteroid-induced immunosuppression and infection with the intestinal nematode Trichostrongylus colubriformis on food intake and utilization in both immunologically naïve and competent sheep. Animal, v.80, p.89-99, 2005.

GREER, A.W.; HUNTLEY, J.F.; McKELLAR, A. et al. The effect of corticosteroid treatment on local immune responses, intake and performance in lambs infected with Teladorsagia circumcincta. International Journal for Parasitology, v.38, p.1717-1728, 2008a.

GREER, A.W.; SEDCOLE, R.J.; JAY, N.P. et al. Protein supply influences the nutritional penalty associated with the development of immunity in lambs infected with Trichostrongylus colubriformis. Animal, v.3, n.3, p.437-445, 2008b.

HOUDIJK, J.G.M.; KYRIAZAKIS, I.; JACKSON, F. et al. The expression of immunity of Teladorsagia circumcincta and its relationship to protein nutrition depend on body protein reserves. Parasitology, v.122, p.661-672, 2001.

HOUDIJK, J.G.M.; KYRIAZAKIS, I.; JACKSON, F. et al. Is the allocation of metabolisable protein prioritised to milk production rather than to immune functions in Teladorsagia circumcincta infected lactating ewes? International Journal for Parasitology, v.33, p.327-338, 2003.

OUDIJK, J.G.M.; JACKSON, F.; KYRIAZAKIS, I. Nutritional sensitivity of resistance to Trichostrongylus colubriformis in lactating ewes. Veterinary Parasitology, v.160, p.258-266, 2009.

HOWSE, S.W.; BLAIR, H.T.; GARRICK, D.J. et al. A comparison of internal parasitism in fleece-weight selected and control Romney sheep. Proceedings of the New Zealand Society of Animal Production, v.52, p.57-60, 1992.

IPOSU, S.O.; McANULTY, R.W.; GREER, A.W. et al. Does suckling offer protection to the lamb against Teladorsagia circumcincta infection? Veterinary Parasitology v153, p.294-301, 2008.

JACKSON, F.; BARTLEY, D.; BARTLEY, Y. et al. Worm control in sheep in the future. Small Ruminant Research, v.86, p.40-45, 2009.

KAHN, L.P.; KNOX, M.R.; GRAY, G.D. et al. Enhancing immunity to nematode parasites in single-bearing Merino ewes through nutrition and genetic selection. Veterinary Parasitology, v.112, 211-225, 2003

KAMBARA, T.; McFARLANE, R.G. Changes in T-cell subpopulations of sheep due to age and dietary protein intake: association with protective immunity to Trichostrongylus colubriformis. Veterinary Immunology and Immunopathology, v.51, p.127-135, 1996.

KIMAMBO, A.E.; MACRAE, J.C; WALKER, A. et al. Effect of prolonged subclinical infection with Trichostrongylus colubriformis on the performance and nitrogen metabolism of growing lambs. Veterinary Parasitology, v.28, p.191-203, 1988.

KENYON, F.; GREER, A.W.; COLES, G.C. et al. The role of targeted selective treatments in the development of refugia-based approaches to the control of gastrointestinal nematodes of small ruminants. Veterinary Parasitology, v.164, p.3-11, 2009.
LE JAMBRE, L. Le Jambre's co-evolution theory. In: _ Turn the worm. New South Wales: Department of Primary Industries, 2005 v.19, p.12-13.

LEYVA, V.; HENDERSON, A.E.; SYKES, A.R. Effect of daily infection with Ostertagia circumcincta larvae on food intake milk production and wool growth in sheep. Journal of Agricultural Science, v.99, p.249-259, 1982.

LOBLEY, G.E.; HOSKIN, S.O.; McNEIL, C.J. Glutamine in animal science and production. Journal of Nutrition, v.131, 25252531, 2001.

McANULTY, R.W.; FAMILTON, A.S.; SEDCOLE, R.J. et al. Changes in the resistance of the ewe to infection with Teladorsagia circumcincta during late pregnancy and early lactation. Animal Science, v.72, 159-168, 2001.

McLURE, S.J.; EMERY, D.L. Trichostrongylus colubriformis and Harmonchus contortus infections in light bodyweight Merino lambs. Australian Veterinary Journal, v.85, p.437-445, 2007.

MORLEY, N.S. Effect of immunosuppression on host-parasitic interactions in sheep infected with $H$. contortus. 2006. PhD Thesis, University of Armidale, NSW, Australia.

MORRIS, C.A.; CLARK, J.N.; WATSON, T.G. et al. Faecal egg count and food intake comparisons of Romney single-trait selection and control lines. New Zealand Journal of Agricultural Research, v.39, p.371-378, 1996.

MORRIS, C.A.; VLASSOFF, A.; BISSETT, S.A. et al. Continued selection of Romney sheep for resistance or susceptibility to nematode infection: estimates of direct and correlated responses. Animal Science, v.70, p.17-27, 2000.

MORRIS, C.A.; WHEELER, M.; WATSON, T.G. et al. Direct and correlated responses to selection for high or low faecal nematode egg count in Perendale sheep. New Zealand Journal of Agricultural Research, v.48, p.1-10, 2005.

NAGASINHA, C. Effects of Trichostrongylus colubriformis on phosphorus and protein metabolism in sheep. $\mathrm{PhD}$ Thesis - Lincoln University, Lincoln, New Zealand, 2000.

O'SULLIVAN, B.M.; DONALD, A.D. A field study of nematode parasite populations in the lactating ewe. Parasitology, v.61, p.301-305, 1970.

POMROY, W.E. Internal helminth parasites of ruminants in New Zealand. In: BARRELL, G.K. (Ed.) Sustainable control of internal parasites in ruminants. New Zealand: Lincoln University Press, 1997. p.11-22.

SYKES, A.R. Manipulating host immunity to improve nematode parasite control - Quo vadit. Parasite Immunology, v.30, p.71-77, 2008.

SYKES, A.R.; COOP, R.L. Intake and utilization of food by growing lambs with parasitic damage to the small intestine caused by daily dosing with Trichostrongylus colubriformis larvae. Journal of Agricultural Science, v.86, 507-515, 1976.

SYMONS, L.E.A.; STEEL, J.W.; JONES, W.O. Effects of level of larval intake on the productivity and metabolic responses of lambs infected with Ostertagia circumcincta. Australian Journal of Agricultural Research, v.32, p.139-148, 1981.

van HOUTERT, M.F.J.; SYKES, A.R. Implication of nutrition for the ability of ruminants to withstand gastrointestinal nematode infections. International Journal for Parasitology, v.26, p.1151-1167, 1996.

VAN WYK, J.A.; BATH, G.F. The FAMACHA system for managing haemonchosis in sheep and goats by clinically identifying individual animals for treatment.Veterinary Research, v.33, p.509-529, 2002.

VAUGHAN, A.L.; GREER, A.W.; McANULTY, R.W. et al. Plasma protein loss in lambs during a mixed infection of Trichostrongylus colubriformis and Teladorsagia circumcincta - a consequence of the immune response. Proceedings of the New Zealand Society of Animal Production, v.66, p.83-87, 2006. 
WATSON, D.L.; COLDITZ, I.G.; ANDREW, M. et al. Agedependent immune response in Merino sheep. Research in Veterinary Science, v.57, p.152-158, 1994.

WEST, D.M.; POMROY, W.E.; KENYON, P.R. et al. Estimating the cost of subclinical parasitism in grazing ewes. Small Ruminant Research, v.86, p.84-86, 2009.

YU, F.; BRUCE, L.A.; CALDER, A.G. et al. Subclinical infection with the nematode Trichostrongylus colubriformis increases gastrointestinal tract leucine metabolism and reduces availability of leucine for other tissues. Journal of Animal Science, v.78, p.380-389, 2000.

ZARALIS, K.; TOLKAMP, B.J.; HOUDIJK, J.G.M. et al. Consequences of protein supplementation for anorexia, expression of immunity and plasma leptin concentrations in parasitized ewes of two breeds. British Journal of Nutrition, v.101, p.499-509, 2009. 